\title{
Retention of Menstrual Fluid in One-half of a Double Vterus.
}

At the meeting of the Obstetrical Society, held February 1, Dr. Galabin relaterl the case of a patient, agerl fifteen, who was bronght by her mother for eonsultation for srmptoms exatly resembling those of ordinary severe spasmorlie dysmenorrhasa. Foswclling or tumour hat been noticed. Menistruation was fairly regular, and rather profuse. The pain was felt ehiefly during the flow, was internittent, agonizing in severity, and led to retehing and lysterieal manifestations. On examination, a firn globular swelling, withont any fluctuation or elasticity, about as large as the uterus at three months and a ladf pregnancy, was felt throngh the anterior vaginal wall. The os was diffieult to discorer, and was displaced badkwards and flattened antero-posteriorly. The paticnt was so hyperasthetic that it was impossible to attemptt to use the sounl. 'I"he author rejected the liypothesis of fibroid tumour on acrount of the patient's youtl, and the commeneement of the symptoms with pulberty, and felt sure that menstrual fluid would not accumulate to any amomut in the uterus if there were any cxit whatever througl the ecrvix. He therefore riagnosed retention in one-half of a double uterus. It was agreed with 1)r. Stirling, of Gumgeroad, under whose eare the patient had been, that an anasthetic shonld be giren, and the swelling evarmated if the diagnosis appeared to be contirmed on use of the sound. Under anasthetics it was found that the somul passed easily to the normal length, going rather towarls the right sirle, and the os appeared to be displaced a little to the right. The swelling was then punctured, and the usual treacly fluid, scen in eases of retained menses, began to escalpe. The opening was cularged with scalpel and director, till it easily armitted the finger, and about ten ounces of fluid eseaperl. Yo injection was nserl on the spot, but it was intenderl to commence antiseptic injections, after allowing a few hours for complete escape of the fluid. The extreme lyyperastlesiat and hysterical resistance of the patient, however, male it impossible to do more than syringe the vagina. 1)ischarge of samguineous thisl was firee up to the third day, but it then almost stopped, and whit there was beenne offensive. Next day felrile symptoms set in, the temperature rising to $104.6^{\circ}$, pulse to 140 . The patient's friends refilserl to allow an andrsthetic to be given to wash ont the uterus until the seventh rlay, when the anthor saw her again. 'There was then still high fever, but no sign of peritonitis. An anastletic having been giren, the opening into the left lalt of the nterus was again enlarged, and the cavity washed out with solution of alssolute phenol, 1 in 40. Consideralle improvement followed np to the twelith clay, although it still proved to be impossible to do more thau syringe tle vagina, and little donbt was felt abont the patient's recovery. On the twelfth day slee was surlelenly attacked with violent pain in the abdomen and eollapse, and alied in about twelve hours. The anthor thought that the symptoms pointed to rupture citlier of the Fallopian tube or of some abscess in the neighrbourloood.

Dr. Grairy II wwitr's experienee had led him to the eonclusion that it was safer, in performing the operation for retained menses, to mike a small opening and allow gratual escupe of fluid, and gradual contraction of the walls of the cavity, which were often weak and thin. If allowerl to clischinge itself too quickly a suction might afterwards be exercised, and septic material drawn in.

Dr. GEuris thought that Dr. Galabin had himself pointerl ont what would have been the most nseful addition to the eonduct of the case, the washing ont with antiseptic fluid the uterine cavity. He agreed with Dr. IIewitt as to the inportance of moderately slow evacuation, but with antisc ptic precautions, thinking that the danger was less through any uterine suetion than through decomposition of unremoved fluid. 
Dr. Wynn Williams differed from Dr. Graily Hewitt in that he had made a very firee opening, to get rid of all the meustrual fluid at onee. He wonld have syringed out the uterus with a solntion of iodine, which he bolieved the safest and best antiseptic. He would also have avoided making a second incision, any septic condition being present.

Dr. Cinamparers had seen a ease of retained menses in one-half of a double uterus, under Dr. Winckel, of Dresden. In this slow evacuation did not prevent a fatal result, which was caused by the retraction of the uterus from an adhesion, which tore a hole in the thin uterine wall. Deatl resulted from septic peritonitis.

Dr. Cleveland was surprised at the fear expressed as to the use of carbolic aeid injections. In cluronic inflammation of the bladder he had used injections of absolute phenol, 1 in 50 or 60 of water, with excellent results.

$\mathrm{D}_{1}$. CAnTEx agreed with what had been said as to the dangerous results which had at times followed the injection of a solntion of earbolic acid into the uterus. He related the case of a paticnt who was for some time in a very critical state after washing out the uterus the third day after a miscarriage with a solution of the strength of 1 in 80 .

Dr. MALiNs thought there was some doubt abont Dr. Galabin's diagnosis in the absence of an autopsy. The symptoms and physical state did not seem inconsistent either with an anterior hamatocele or thrombus in the cellulur tiswe. He had met with similar cases in which the difficulty in insuring drainage and disinfection had been overcome by using a winged eatheter with the end cut off. He thought nothing better than tinctnre of jodine for disinfection.

Dr. Routh eould not agree with Lr. Hewitt in his allvice to make a small openiug. Experience proved that it often closed, and oceasionally was followed by fatul symptoms. His own plan was to draw off by a large aspirator, and to inject iodine solution, doing this morning and evening, and keeping in a drainugetube.

Dr. Mattmews Duxcan remarked that he, in cases of retained menses, made a fice opening and allowed the fluid to drain away, nsing no injection of any kind. He hal in a considerable experience had no fatal case or evil result, and he believed he had obsred jnjurious consernences of the injection of plain warm water in cases which he lad witnessed.

Dr. GarabiN thought that the plan of gradnal evacuation was desirable when the quantity of retained fluid was large, but not when it was small or moderate. He did not think the fatal result in his case could be attributed to the injection of carbolic acid, or cven to the second incision; for a marker inprovement litd followed that procecling, and continued for at least four days. He did not believe the case coukl have been one of liamatoeele, for the swellingr had been perfectly movable, and he did not think that the contents of a hamatocele ever so perfectly resemblet the uniform trealy fluid seen in eases of retained menses. -Lancet, March 11, 1882.

\section{Unilateral Vaginal Oöjhorectomy.}

Dr. Braitifinate, of Leeds, read a paper on the above subject at the meeting of the Obstetrical Soeiety of London, on April 5th.

Case 1. The patient, aged 30 , was the wife ot a workman. She suffered from attadks of dyspnoea, which were brought ou by exertion, and which could only be relievel by eertain very peenliar positions of the borly. There was a mitral murmur: the patient was pale, and in wretched general health, and the nuscle of the heart probably extremely feeble. Menstruation was normal. There was a prolapsed ovary, pressure on which did not bring on the dyspneea, but eaused much 